\title{
Cellular gene expression survey of PseudoRabies Virus (PRV) infected Human Embryonic Kidney cells (HEK-293)
}

\author{
Yannick BLANCHARD ${ }^{\mathrm{a}, \mathrm{b} *}$, Nolwenn LE MEUR ${ }^{\mathrm{c}}$, Martine LE CUNFF $^{\mathrm{c}}$, \\ Philippe BLANCHARD ${ }^{\mathrm{a}}$, Jean LÉGER ${ }^{\mathrm{c}}$, André JESTIN ${ }^{\mathrm{a}}$ \\ a Laboratoire de Génétique Virale et Biosécurité, Agence Française de Sécurité Sanitaire des Aliments, \\ BP 53, 22440 Ploufragan, France \\ ${ }^{\mathrm{b}}$ Zoopôle Développement, 7 rue Jean Rostand, 22440 Ploufragan, France

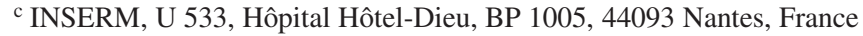

(Received 23 September 2005; accepted 21 February 2006)

\begin{abstract}
Pseudorabies virus (PRV) is an alpha herpesvirus that causes Aujezsky disease in the pig. To characterize the impact of PRV infection on cellular expression, we used microarrays consisting of 9850 oligonucleotides corresponding to human genes and examined the expression levels of mRNA isolated 0.5, 3, 6, and $9 \mathrm{~h}$ post infection (hpi) from cultures of infected HEK-293 cells. Very few changes were observed during the first $3 \mathrm{~h}$ of infection but significant modifications in the cell expression of more than 1000 genes were clearly apparent by 6 hpi. More than 2400 genes were either up- or down-regulated during the $9 \mathrm{~h}$ experiment. These results were then analyzed using gene ontology and the MAPP and MAPPFinder software. This comprehensive analysis clearly shows that the down-regulated genes were mainly involved in macromolecular synthesis (DNA, RNA and proteins) and the cell cycle. The up-regulated genes primarily concerned the regulation of DNA transcription, developmental processes (central nervous system development, neurogenesis, angiogenesis), cell adhesion and potassium transport. This study is the first qualitative analysis of a gene expression survey in a human cell line following PRV infection. It demonstrates global changes in the cell expression profile, and identifies the main biological processes that are altered during virus replication.
\end{abstract}

pseudorabies virus / microarray / host pathogen interaction

\section{INTRODUCTION}

PseudoRabies Virus (PRV) is a swine alpha herpes virus responsible for Aujezky disease. It has a broad range of animal hosts but, apart from rare cases of pruritus [26] is generally considered non-infectious to humans. PRV is a close homologue of Varicella-Zoster Virus (VZV) and Herpes

*Corresponding author: y.blanchard@afssa.fr
Simplex Virus 1 (HSV-1) and displays an almost one to one gene correspondence with this latter. From the large number of reports and the incorporation of its genome sequence into the database of Sexually Transmitted Diseases [20], PRV may be considered as a model for alpha herpes virus biology.

Productive infections of PRV, as of all alpha herpes viruses, induce major changes in the infected cell that ultimately lead to 
host destruction. We therefore studied the kinetics of the PRV lytic cycle to obtain an overall view of the multiple virus-host interactions that occurred during it by using a microarray approach. Microarrays are an extremely powerful technique for studying the impact of viral infection on gene expression and have recently been used by virologists to this end. This approach has either been used to study the virus transcription program [27, 34], or to determine the impact of viral infection on cell physiology $[5,17,36]$. It has also been used recently to screen the virus species in emerging diseases, in which case, a microarray composed of thousands of oligonucleotides has been designed and constructed to cover the different virus families, genera and species [42].

The microarray approach should potentially have two major advantages for viral disease studies: (1) it should speed up identification of the virus species involved (the virus responsible for SARS was partially identified and sequenced from samples in less than one week by DeRisi's lab using a pan viral microarray [43]), (2) it should allow blind studies in which no prior knowledge about the virus or its impact on cell physiology is required, with the very large number of targets deposited on the micro array covering most of the cellular processes and demonstrating any significant alterations in one or several of these. Large scale analysis of the virus host interaction should then confirm or reveal those cellular targets of interest in understanding the virus and its action on cell physiology and eventually, help to identify potential targets for use in the control of viral infection.

We used a pan genomic approach in this study to profile cellular gene expression during a PRV lytic infection of the human cell line HEK-293. We chose a human cell line (1) because although PRV is non infectious to humans, "in vitro" human cell lines are readily infected by PRV [3], with cell entry being mediated by members of the immunoglobulin super family (nectin-1 and nectin-2) [23], and resulting in productive viral infections in this particular cell line; (2) because human DNA chips, unlike porcine chips, were readily available from different companies. The use of a human cell host in the widely studied PRV model might also be of interest in comparing the expression profiles of alpha herpes virus of different origins.

\section{MATERIALS AND METHODS}

\subsection{Cells and virus}

Human embryonic kidney cells (HEK-293) and PK15 were grown in EMEM containing $5 \%$ fetal calf serum and $100 \mathrm{U}$ Penicillin $/ \mathrm{mL}$ and 100 U Streptomycin sulfate $/ \mathrm{mL}$. The cells were regularly tested for the absence of mycoplasm contamination. The stock of PRV (NIA-3 strain) used in this study was prepared as follows: confluent PK15 were infected with PRV overnight. When $80 \%$ of the infected cells presented cytopathogenic effects (CPE), cell culture was stopped by freezing at $-80{ }^{\circ} \mathrm{C}$. After two cycles of freeze-thawing, virus-containing media were centrifuged (1 $800 \mathrm{~g}, 30 \mathrm{~min}$, $4{ }^{\circ} \mathrm{C}$ ) and the supernatant was aliquoted and stored at $-80^{\circ} \mathrm{C}$. For the mock infection experiment, a PK15 cell supernatant was produced according to the same protocol but with no addition of virus.

\subsection{PRV infection of HEK-293}

The HEK-293 cells were seeded at a density of $2.10^{5}$ per $\mathrm{cm}^{2}$ two days before infection, then infected with 6 MOI PRV under gentle agitation for $1 \mathrm{~h}$ at $37{ }^{\circ} \mathrm{C}$. HEK-293 conditioned medium was then added and culture was continued. Mock infected cells were seeded and incubated with a PK15 virus-free supernatant under the same conditions. At $0.5,3,6$ and $9 \mathrm{~h}$ 
post infection (hpi), the cell cultures (mock and infected cells) were stopped by removing the culture medium, replacing it with $8 \mathrm{~mL}$ of Trizol ${ }^{\mathrm{TM}}$ (Life Technologies, Rockville, USA) and freezing at $-80{ }^{\circ} \mathrm{C}$ before RNA extraction.

\subsection{RNA purification and hybridization to gene chip}

Frozen Trizol suspensions were thawed and the total RNA was purified according to the manufacturer's protocol (Invitrogene, Cergy Pontoise, France). Poly (A) + mRNA affinity purification was performed with the oligotex mRNA purification kit (Quiagen, Valencia, CA, USA). One microgram of purified mRNA was used as a template for cDNA synthesis with the Cyscribe cDNA post labeling kit (Amersham, Little Chalfont, UK) according to the instructions. Post labeling with Cyanine 3 or 5 was performed with the same kit. RNA extracts from mock infected samples were labeled with Cy3 and PRV infected samples were labeled with Cy5 for most of the experiments, however flap dying between $\mathrm{Cy}$ 3 and Cy5 was performed for some experiments. For each step of the preparation (i.e. RNA, mRNA purification and cDNA synthesis), sample quality was assessed by capillary electrophoresis with the Bioanalyser 2100 (Agilent Technologies, Waldbronn, Germany). These controls allowed precise evaluation of rRNA contamination after oligotex mRNA purification and of the yield in cDNA synthesis after the reverse transcription and resulted in a more accurate overall $\mathrm{Cy} 3 / \mathrm{Cy} 5$ ratio for the hybridization experiment. Hybridization was performed overnight at $42{ }^{\circ} \mathrm{C}$ on human pan array set A, representing 9850 human genes, from MWG (MWG, Ebersberg, Germany) in an ArrayIt ${ }^{\mathrm{TM}}$ hybridization chamber (Telechem, Sunnyvale, CA, USA), according to the manu- facturer's instructions. Scanning was performed at $10 \mu \mathrm{m}$ resolution with a ScanArray Express (Packard Biosciences, Wellesley, MA, USA). Each infection experiment was repeated three times except for the 9 hpi time point which was repeated 4 times. Each time point was kept separately throughout the experiment except for the mock infected cells that were pooled to provide a homogeneous baseline between the different hybridizations.

\subsection{Data Analysis}

Data were analyzed with the Genepix Pro (version 4.0) analysis software (Axon Instruments, Union City, CA, USA). Raw data were normalized with the MADSCAN $^{1}$ suite according to the instructions. The SAM (Statistical Analysis of Microarray) software was used for statistical analysis of the data [39]. The one class response analysis was conducted for each time point of the kinetic experiment compared to the uninfected control. Self Organizing Map (SOM) clustering experiments were carried out with Acuity (Axon Instruments, Union City, CA, USA) using Euclidian square similarity metrics. The Gene Ontology analysis of the data was performed with MAPPFinder and GenMAPP $[7,8]$ two freely available software developed by B. Conklin's group at the Gladstone Institute. Two strategies were used. The first analysis was conducted on all the results with separate analyses of the up- and down-regulated genes. A second analysis was then conducted on the SOM $3 \times 3$ cluster results (presented in Supplementary data $^{2}$ ). Briefly, the MAPPFinder analysis provides a file of gene ontology terms organized in a tree-like structure which defines any parent-child relationships existing between these terms. Each

\footnotetext{
${ }^{1}$ http://cardioserve.nantes.inserm.fr/mad/madscan. ${ }^{2}$ Supplementary data are available online only at www.edpsciences.org.
} 
Table I. Primers and probe set identities utilized for the RT-PCR.

\begin{tabular}{|c|c|c|}
\hline Assay ID & Gene name & $\begin{array}{l}\text { NCBI gene } \\
\text { reference }\end{array}$ \\
\hline Hs00276000_m1 & CD27-binding (Siva) protein (Interim) & NM_006427 \\
\hline Hs00197387_m1 & Protein $\mathrm{C}$ receptor, endothelial (EPCR) & NM_006404 \\
\hline Hs00174774_m1 & Lectin, galactoside-binding, soluble, 3 binding protein & NM_005567 \\
\hline Hs00194264_m1 & $\begin{array}{l}\text { Interferon gamma receptor } 2 \text { (interferon gamma } \\
\text { transducer 1) }\end{array}$ & NM_005534 \\
\hline Hs00268858_s1 & G protein-coupled receptor 68 & NM_003485 \\
\hline Hs00173615_m1 & Pentaxin-related gene, rapidly induced by IL-1 beta & NM_002852 \\
\hline Hs00182064_m1 & Microsomal glutathione S-transferase 2 & NM_002413 \\
\hline Hs00153957_m1 & Advanced glycosylation end product-specific receptor & NM_001136 \\
\hline Hs00174200_m1 & Interleukin 5 (colony-stimulating factor, eosinophil) & NM_000879 \\
\hline Hs00277299_m1 & Interleukin 1 receptor antagonist & NM_000577 \\
\hline Hs00174097_m1 & Interleukin 1 , beta & NM_000576 \\
\hline Hs00166223_m1 & Interferon gamma receptor 1 & NM_000416 \\
\hline Hs00164957_m1 & $\begin{array}{l}\text { Integrin, beta } 2 \text { (antigen CD18 (p95), lymphocyte } \\
\text { function-associated antigen 1; macrophage antigen } 1 \\
\text { (mac-1) beta subunit) }\end{array}$ & NM_000211 \\
\hline
\end{tabular}

term is associated with a $\mathrm{z}$ score which varies according to (1) the number of genes satisfying a given criterion and (2) the number of genes corresponding to this term in the gene ontology. For a given GO term, if only a small percentage of genes satisfies the criterion the $\mathrm{z}$ score will be close to 0 . This $\mathrm{z}$ score will increase with the number of genes satisfying the criterion. Only those terms with $\mathrm{z}$ scores equal or greater than 2 were considered for further analysis.

\subsection{Real Time RT-PCR}

Five micrograms of total RNA were treated with DNA-Free (Ambion, Austin, TX, USA) to remove any potentially contaminating DNA then reverse transcribed with the high capacity cDNA archive kit (Applied Biosystems, Foster city, CA, USA) according to the manufacturer's protocols. Primers, probe sets and protocols used for the real time PCR were from Applied Biosystems (Assays on Demand) (Tab. I). The thermal cycling conditions were $2 \mathrm{~min}$ at $50{ }^{\circ} \mathrm{C}, 10 \mathrm{~min}$ at $95^{\circ} \mathrm{C}$ and then 50 cycles of $15 \mathrm{~s}$ at $95{ }^{\circ} \mathrm{C}$ followed by 1 min at $60{ }^{\circ} \mathrm{C}$ with an ABIPrism 7000 (Applied Biosystems). We used 18S ribosomal RNA for the internal calibration (ref: Hs99999901_s1; Assay on Demand, Applied Biosystems).

\section{RESULTS}

\subsection{Statistical data analysis of the PRV infection of HEK-293}

Preliminary experiments were done to assess PRV infectivity of the HEK-293 cells and to determine cycle duration under these experimental conditions (data not shown). A homogeneous response was obtained in the cell cultures at 6 MOI. Major cytopathic effects were apparent in the cultures $12 \mathrm{~h}$ after infection and the yield of extracted RNA at this time was very low (data not shown). The kinetic study was therefore performed over the first $9 \mathrm{~h}$ of infection.

Four time points were analyzed by microarray at $0.5,3,6$ and 9 hpi. For each time point, 3 microarrays were hybridized with 3 biological replicates of 
the infection, i.e. 3 different infection experiments were performed and kept separately throughout the process except for the uninfected controls. The different control cDNA samples were pooled before the hybridizations so that the baseline expression was homogeneous in all the microarrays. The normalized data were analyzed with the SAM program for the statistical evaluation of variant genes. The SAM one-class response data plot for each kinetic point clearly shows an evolution in cellular expression according to the time post infection (Fig. 1). At 0.5 hpi most of the genes were invariants, i.e. distributed within the dashed diagonal lines representing no variation in gene expression, except for 26 genes localized beneath the lower dashed line, that would be under expressed, with the number of false positive genes equal to $0.8(\Delta=0.6)$. However, the down regulation at this time point looked very weak, the log ratio of only one gene being below-1 and no down-regulation was observed in any of these 26 genes at the following time point. At 3 hpi most of the genes were still within the "invariant" limits except for one which was downregulated and 21 up-regulated (i.e. located above the upper dashed line), but with a high number of false positive genes (6.5; $\Delta=0.54)$. At 6 hpi the number of SAMestimated variant genes increased dramatically to 1175 with the false positives equal to $8.4(\Delta=0.85)$. Amongst these 1175 variant genes 459 were up-regulated and 716 down-regulated. By 9 hpi, the estimated number of variant genes had risen to 2355 with 907 up-regulated genes, 1468 down-regulated genes and $101.2(4.3 \%)$ false positive genes $(\Delta=0.47)$. According to this statistical analysis, and taking the kinetic study as a whole, 2834 genes were considered as variants with 1137 of these up-regulated and 1697 down-regulated.

A feature of the SAM program is to estimate the number of false positive genes, the operator applying a parameter $(\Delta)$ to control the rigorousness of this estimation. The more stringent the $\Delta$ parameter, the fewer the false positive genes but also the fewer the true positive genes. A balance has to be found between a highly stringent $\Delta$, that will eliminate many truly variant genes, and a low $\Delta$, that will give a large number of probably variant genes but also a rather high level of false positives. No threshold value was fixed in this statistical analysis, but the selection of a gene as variant or invariant was instead based essentially on the SAM analysis and sometimes resulted in the selection of genes with slight but reproducible variations in expression. Figure 2 shows the distribution of the variant genes according to the normalized $\log 2$ ratio. It can be seen that the normalized $\log 2$ ratio of the vast majority $(91 \%)$ of the variant genes is above 0.7 .

\subsection{Real time RT-PCR validation of the microarray results}

The validity of the results obtained by microarray analysis was checked using a real time RT-PRC approach on a sample of 13 genes selected to cover a large range of normalized $\log 2$ ratios from -1.5 to +3.7 with various intermediate values. The results are displayed in Table II and Figure 3. Five and eight genes were down- and upregulated respectively and all were variant genes according to our SAM analysis except for the gene identified as NM_006427. Figure 3 is a bar representation of the results obtained at 9 hpi. The real time PCR confirmed the results for all the tested genes that were down-regulated according to microarray. Most of the up-regulated genes evidenced by microarray were validated by real time PCR except for three (NM_00604; NM_003485; NM_000879) which were considered as invariants by real time PCR. The three up-regulated genes that were not validated by real time PCR, were evenly distributed along the range of positive ratios and, surprisingly, the gene 

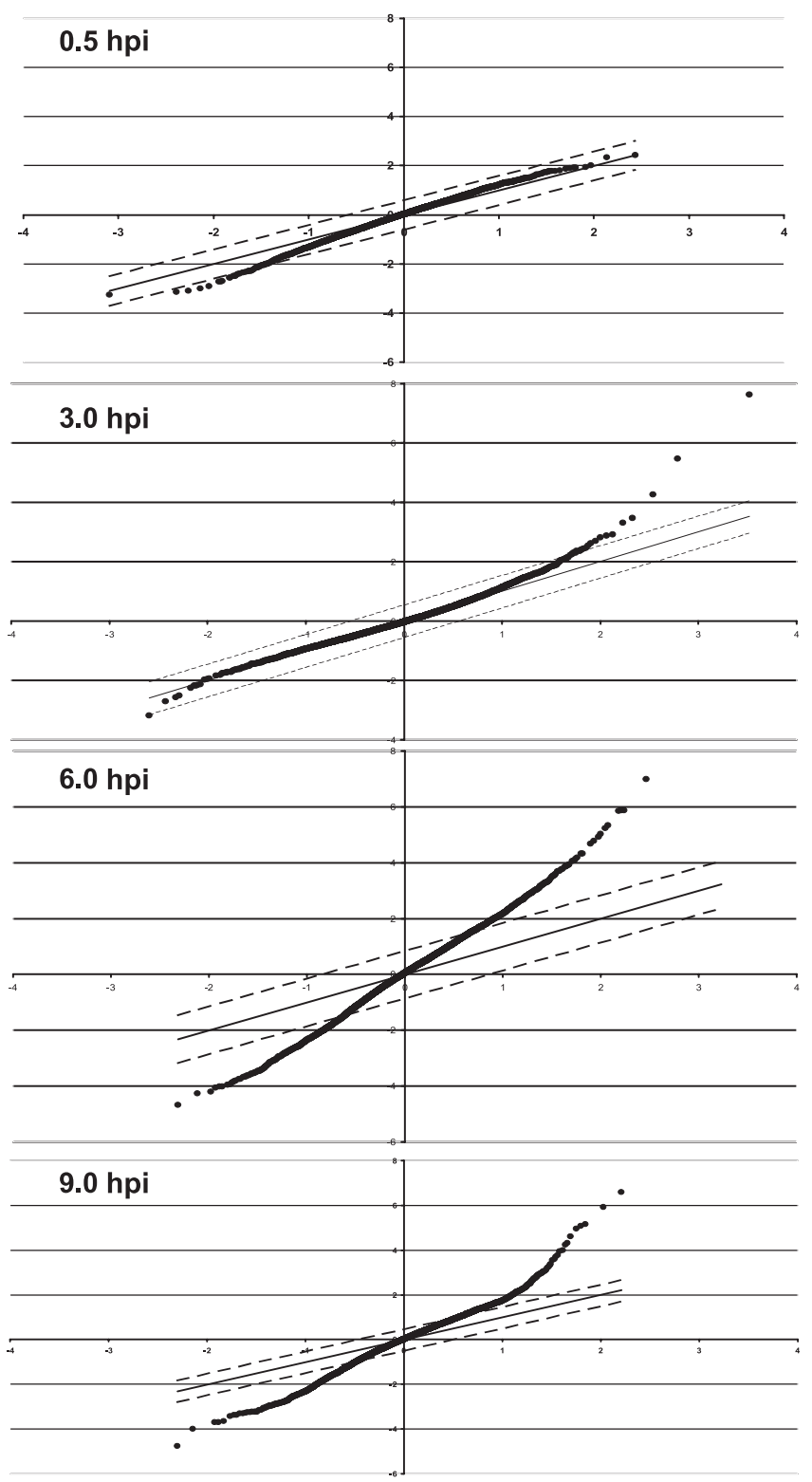

Figure 1. SAM graphical representation of the one class analysis of the microarray data. One class analysis was performed with 3 microarrays for times $0.5,3$ and $6 \mathrm{~h}$ post infection and with 4 microarrays for the $9 \mathrm{~h}$ time point. The full line is the theoretical distribution of the values and the dashed lines define the significant field. Dots contained within these lines are considered invariants, dots outside the dashed lines are probable significantly up-regulated genes (above the upper line) or probable significantly down-regulated genes (below the lower line). The number of genes outside the dashed lines, i.e. the variant genes, increases with time. 
Table II. Validation of array data by real-time PCR.

\begin{tabular}{lrrrrrrrr}
\hline \multicolumn{9}{c}{ Real time PCR } \\
\hline & 0.5 & 3 & 6 & 9 & 0.5 & 3 & 6 & 9 \\
NM_002413 & 0.37 & -0.06 & -0.56 & -0.46 & 0.03 & 0.16 & $-{ }^{\mathrm{a}}$ & -1.49 \\
NM_000416 & 0.27 & -0.34 & -1.2 & -1.46 & - & - & - & -1.04 \\
NM_005534 & 0.33 & 0.06 & -0.48 & -0.57 & 0.16 & 0.02 & -0.32 & -0.67 \\
NM_005567 & 0.52 & -0.06 & -1 & -1.5 & -0.11 & -0.01 & -0.43 & -0.62 \\
NM_006427 & 0.42 & 0.21 & -0.41 & -0.94 & 0.052 & 0.31 & 0.25 & -0.18 \\
NM_006404 & 0.38 & 0.02 & -0.26 & -0.06 & 0.21 & -0.09 & 0.61 & 0.69 \\
NM_001136 & 0.5 & 0.76 & 0.9 & 1.04 & -0.03 & -0.012 & 0.47 & 0.74 \\
NM_000211 & 0.28 & -0.46 & -2.8 & 0.61 & -0.07 & -0.06 & 0.53 & 0.85 \\
NM_002852 & 0.36 & 0.14 & 0.7 & 0.53 & 0.15 & -0.02 & 0.45 & 0.95 \\
NM_000757 & 0.4 & 0.202 & -0.2 & 2.08 & - & 0.12 & - & 1.21 \\
NM_003485 & 0.33 & 0.55 & -1.3 & -0.03 & 0.22 & 0.19 & - & 1.65 \\
NM_000577 & -0.06 & -0.28 & 0.11 & 2.17 & - & - & - & 2.17 \\
NM_000879 & 0.65 & -0.72 & 0.95 & -0.3 & - & - & - & 3.71 \\
\hline
\end{tabular}

a absent.

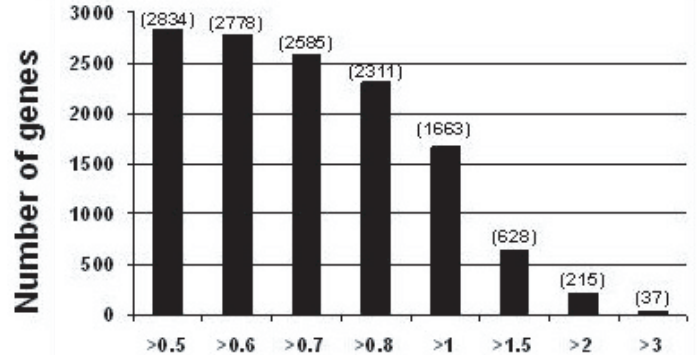

Fold Increase
Figure 2. Total number of variant genes according to the distribution of the normalized $\log 2$ ratio in PRVinfected cells versus mock infected cells (in brackets the number of genes above this ratio). with the highest ratio $(+3.7)$, was invalidated by real time PCR. Seventy-five percent of the genes were validated by real time PCR but if we considered only the up regulated genes this value would only be $62 \%$.

\subsection{Data clustering analysis}

The expression patterns for the SAM variant genes were then projected on a 3 by 3 grid following a self-organizing map algorithm (Fig. 4). The number of genes present in the different clusters was highly heterogeneous, ranging from 22 to 590 . Four clusters (numbers 1, 4, 5, and 7) represented those up-regulated genes that corresponded to different kinetics of activa- tion: -cluster 5 (22 genes - $0.8 \%$ ) displayed maximum activation by 3 hpi followed by a constant expression ratio level until the end of the experiment, -cluster 4 (321 genes - $11.3 \%$ ) represented genes that were strongly up-regulated at $6 \mathrm{hpi}$ but which showed a slight increase in the expression ratio by 9 hpi, -cluster 7 (170 genes $-6 \%$ ) was similar to cluster 4 but the expression ratio had slightly decreased by 9 hpi, -cluster 1 (384 genes $-13.5 \%$ ) consisted of genes for which the expression ratio showed a regular increase over the experimental period and peaked at 9 hpi. The down-regulated genes were also distributed between four clusters: -clusters 3 (196 genes $-6.9 \%)$ and 6 (457 genes $-16.12 \%$ ) were stable during the first $3 \mathrm{~h}$ 


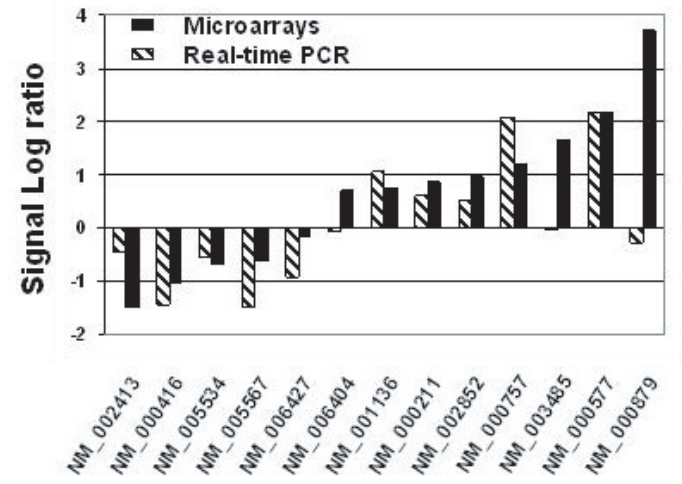

Figure 3. Real time PCR analysis of a sample of variant genes according to the microarray profiling results for the infection of HEK 293 by PRV. Values corresponding to the peak of induction or repression obtained by microarray are shown together with the real time PCR results obtained at the same time. of the experiment, decreased by $6 \mathrm{~h}$, and by $9 \mathrm{~h}$ showed a slight increase (cluster 3 ) or a slight decrease in expression (cluster 6), -cluster 8 (205 genes $-7.2 \%)$ represented genes which were stable throughout the 6 first $h$ of the experiment then decreased by 9 h, -cluster 9 (590 genes - 20\%) consisted of genes for which the expression ratio showed a regular decrease over the different time points of the experiment. Cluster 2 (72 genes $-2.5 \%$ ) displayed a seemingly doubtful pattern with gene expression moving up and down, i.e. increased by $3 \mathrm{~h}$, decreased by $6 \mathrm{~h}$ then increased again by $9 \mathrm{~h}$. Only 2435 (85.9\%) of the 2834 genes subjected to the SOM cluster experiment, fell within the SOM $3 \times 3$ matrix, 397 genes did not group with any of the clusters because of poor representation at the different time points. Amongst these 397 variant genes, 166 were downregulated and 231 were up-regulated. The list of genes present in the different clusters is given in Supplementary data ${ }^{2}$ Table I and the result of the MAPPFinder analysis in the gene ontology SOM cluster file.

\subsection{Gene Ontology analysis}

To obtain a comprehensive view of the events occurring during the lytic infection of HEK cells by PRV, the results were then subjected to an analysis based on the Gene
Ontology. Amongst the 9870 genes present on the chip, 6991 were expressed in our experiment and could be linked to a GO term $(70.7 \%)$ and were used in further analysis. Some up- and down-regulated genes (295 and 399 respectively) were not referenced in the MAPP software and could not be used in the gene ontology analysis. For clarity, only those GO terms corresponding to the biological process are presented in Table III (in Appendix) (besides the cutoff of 2 for the $\mathrm{z}$ score). The full table of results, with molecular function and component terms, is presented in Supplementary data ${ }^{2}$ Table II and Supplementary data $^{2}$ Table III as is the data source (GEX file $^{3}$ ) used for the MappFinder analysis. In addition to its 3 structuring principles (BP, $\mathrm{MF}$, and $\mathrm{C}$ ), Gene Ontology has a treelike structure, establishing a hierarchy and relationship between some of the terms. This tree structure is partially shown in column 1 (Path) (Tab. III) (details on the Gene Ontology hierarchy can be found at http://www.geneontology.org/).

Two main branches are apparent for the up-regulated genes (Tab. III). One branch concerns cell communication with

\footnotetext{
${ }^{3}$ GEX file is the data set file (available only in electronic form at www.edpscienes.org) used by MappFinder for the visualisation of the Biological pathways. You can downloaded Mappfinder at www.genmapp.org/.
} 

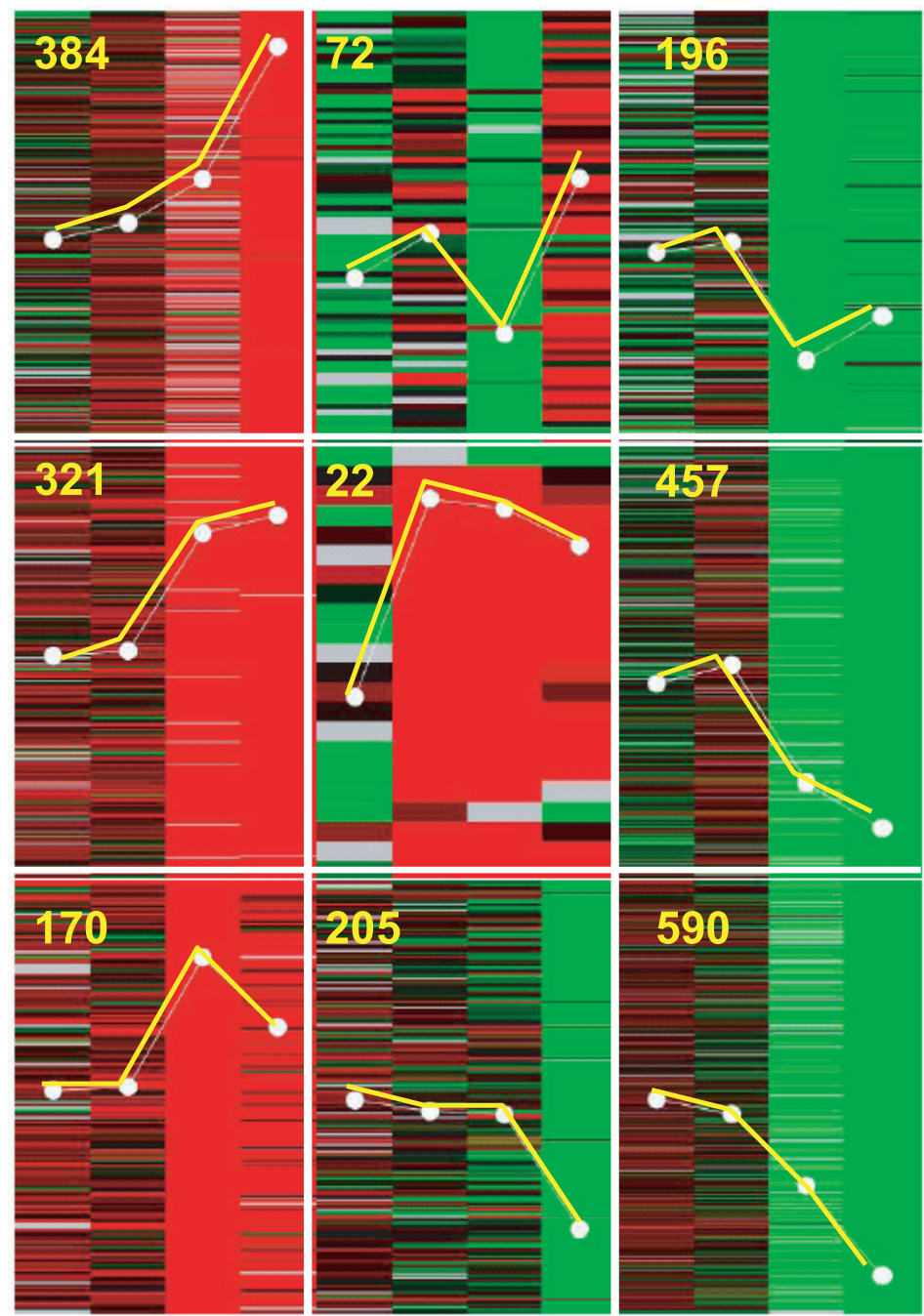

Figure 4. $3 \times 3$ self organization map $(\mathrm{SOM})$ of the variant genes for times $0.5,3,6$ and $9 \mathrm{~h}$ post infection. Lower left cluster ID number. Upper left corner: number of genes present in the cluster. (A color version of this figure is available at www.edpsciences.org.)

82 of the genes exhibiting modified expression. Several of the communication terms are related to the adhesion process: adhesion (GO:7155), cell-cell adhesion (GO:16337, and regulation of cell adhesion (GO:30155) and are all members of the same branch of the tree. This is apparent through the path columns where the 0.0.2.0.0 "root" is common to all three terms. Cell-cell adhesion and regulation of cell adhesion show an extension of the root (cell-cell adhesion: 0.0.2.0.0.2; regulation of cell adhesion: 0.0.2.0.0.5), and this extended path means that they are "children" of the terms with the similar but shorter path. The second main branch that 
appears to be up-regulated is the developmental biological process (GO:7275) with the modified expression of 94 genes and two processes set apart: 34 genes involved in neurogenesis (GO:7399) and central nervous system development (GO:7417) and 7 genes involved in blood vessel development (GO:1568) and angiogenesis (GO:1525). It should be noted that some of the "children" of neurogenesis (GO:7399) are not shown in Table III because their $\mathrm{z}$ score was below 2 (axonogenesis $\mathrm{z}$ score: 1.22; axon guidance $-\mathrm{z}$ score: 1.74). The other principal biological processes that were up-regulated were not associated with a particular path, e.g. the regulation of transcription (DNA dependent) (99 genes) (GO:45449), potassium ion transport (18 genes) (GO:6813) and antimicrobial humoral response (14 genes) (GO:6960).

Although the number of biological processes associated with the downregulated genes was much higher (Tab. III) all these processes were gathered under a limited number of main "branches". The first one is cell organization and biogenesis (GO:16043) (39 genes) which includes the organization of different cellular structures i.e. the cytoskeleton, microtubule, endoplasmic reticulum, lysosome, ribosomes, and chromosomes. The second main branch of the tree represents cell proliferation (G0: 8283) (133 genes), for which down-regulation of the genes seems to be general to this process: DNA replication (GO: 67), chromosome condensation and segregation (GO: 30261 and 7059), transition between the different phases of the mitotic cycle $(\mathrm{G} 1 / \mathrm{S}, \mathrm{G} 2 / \mathrm{M})$, and spindle assembly. The third main branch of the tree is related to the transport process (GO:6810) (191 genes) and except for proton transport (GO:15992) essentially concerns protein transport (GO:15031). The fourth main branch of the tree concerns metabolism (GO:8152) (604 genes) and can be divided into four branches that represent nucleotide biosynthesis (GO:9165) (34 genes), DNA metabolism (GO:6259), RNA metabolism (GO:16070) and protein metabolism (GO:19538) with minor branches for carbohydrate catabolism (GO:16052) and electron transport (GO:6118).

We then attempted to determine more precisely the timing of the biological process alterations by applying a similar gene ontology analysis to the same results, but with the different genes distributed in clusters (Fig. 4, see results Supplementary Data $^{2}$ Tab. I). No biological process was significantly altered in the two smallest clusters (numbers 2 and 5 with 72 and 22 genes respectively). The other clusters did reveal changes in biological processes, i.e. the up-regulated genes in clusters 1, 3 and 7 and the down-regulated genes in clusters 3, 6, 8 and 9. Most of the downregulated biological processes were redundant i.e. present in the different "down regulated" clusters (data not shown). In contrast, very little redundancy was apparent between the different clusters of upregulated genes. The biological processes evidenced in this case were essentially the same as in the global analysis (Tab. III), although some additional information was obtained: the gene ontology term "integrinmediated signaling pathway" (GO:7229) in cluster 4 , for example, appears as a "child" of the cell adhesion biological process (GO:7155) which did not come out in the global gene ontology analysis. Also the gene ontology term "synaptic transmission" (GO:7268) in cluster 7 is an upregulated biological process that was not apparent in the global analysis.

\section{DISCUSSION}

In this study we used a pan genomic microarray approach to characterize the impact of PRV infection on the transcriptional activity of a human cell line (HEK-293). 
Although PRV is well referenced in the literature, and provides a model system for the study of alpha herpesvirus biology, several aspects of PRV/host interaction unlike those of its human counterpart [29] remain unknown or are poorly understood. Microarray studies generate a huge amount of data in the form of tedious lists of up- or down-regulated genes. Unless the user already knows a lot about the genes, these lists cannot be exploited without much extra work. We tried to integrate our data in a more informative way using Gene Ontology and other appropriate tools. The principal advantage of gene ontology, especially with regards to the "biological process" aspect, is to integrate the acquired information about the genes and reorganize the list of genes whose expression has been modified during the infection, into a list of gene ontology terms that indicate the main cellular processes that have thus been altered.

An important feature of our results is the very high number of down-regulated genes that can be grouped under a limited number of essential biological processes concerned with DNA, RNA, protein metabolism, and cell proliferation.

Cell infection by alpha herpesvirus is characterized in most, if not all cases, by a rapid control of host cell expression mediated by two complementary shutoff mechanisms, a very early shutoff and a delayed shutoff $[6,12,20,30]$. Although homologous sequences for both mechanisms exist in the PRV genome, no precise functional characterization of the control of host cell expression has been described and according to some reports the early shutoff mechanism might not occur during PRV infection or only function weakly $[2,9,19]$ as described for the Equine herpesvirus 1 [13]. Even though the only variant genes observed after $30 \mathrm{~min}$ of infection, are down-regulated genes, our results do not show any evidence of generalized early shutoff during PRV infection. How- ever, since the rationale of the microarray experiment was to hybridize equivalent amounts of target from the control and test samples to obtain an overall ratio close to one, if a slight early shutoff did occur during PRV infection, it might be obliterated by this necessary technical equilibrium. In contrast, our results implied that delayed shutoff (mediated by the ICP27 protein) is likely to be highly operant as suggested by the very large number of down-regulated genes observed at $6 \mathrm{hpi}$ and thereafter (Fig. 1) and confirmed the results obtained by Tirabassi and Enquist who obtained similar shutoff kinetics in PK15 cells [38]. Several very important biological processes are down-regulated especially those involved in RNA synthesis and maturation or the spliceosome assembly for which an interaction between the HSV1-ICP27 protein and spliceosome-associated protein has already been evidenced [4] (Tab. III). This down-regulation of gene expression is not limited to the metabolism of RNA, however, and is much more general. DNA and protein metabolism are also severely down-regulated, as reflected by the presence of GO terms such as biosynthesis, protein synthesis and metabolism, close to the root in the gene ontology hierarchy. These terms are much too general to provide detailed and useful information on their own, but are linked to much more specific terms that are located deep within the gene ontology hierarchy. One such example is the biological process "regulation of MHC class I biosynthesis" ( $\mathrm{z}$ score $=2.09)$ which contains the Interferon beta precursor (IFN-beta) gene that was down-regulated in our experiment (log ratio $=-0.78$ ). Down regulation during PRV lytic infection has already been reported for this process [1].

Most of the biological processes that appear down regulated according to our GO analysis are supported by previous data from the literature (cell cycle inhibition 
[14], cellular cytoskeleton organization [33], stress actin fiber breakdown [42, 43], etc.).

The up-regulated biological processes, although fewer in number than the downregulated ones, can be grouped together under several more general terms (Tab. III).

Several of these refer to the nervous system (neurogenesis, central nervous system development, neurotransmitter transport), which might seem surprising for an epithelial cell line as the HEK 293. This cell line displays epithelial morphology and is not usually considered to be derived from neuron precursors although a possible neuronal origin has been evoked recently [31]. It is, however, consistent with the characteristic neuronal tropism of alpha herpes viruses, associated with the establishment of lifelong infection, which they reactivate during times of stress [10]. The PRV immediate early protein 180 (IE 180) is known to be a strong transactivator of several promoters [16] and a neuron tropism expression associated with the IE 180 promoter has recently been demonstrated in IE180 transgenic mice [37]. A slight upregulation of other neuron-related biological processes is also observed. Such is the case with "axon guidance" (not shown in Tab. III) for which three genes (FEZ, SPON2, KAL1) showed increased expression. Considering the strong relationships that exist between PRV and the axons [11], this is no more surprising than the result for neurogenesis. The case of the SPON2 gene involved in nerve system patterning [40] referenced on 01/13/2004, by Gene Ontology under the terms described in this article (axon guidance, extracellular matrix) is of particular interest. A recent report [18] strongly suggests that SPON2 is also involved in defense mechanisms and could be essential to initiation of the innate immune response. This information had not been entered into the GO databases when this manuscript was written, and our gene ontology analysis could not integrate this potential dual function of SPON2. It therefore only highlighted the axon guidance role of this gene. We now have to ask for which function SPON2 is over expressed? Is it up-regulated, by the cell, for a role in a defense mechanism or by the virus, to modify some host's adhesion properties. This question is also, of course, relevant to other genes which, like SPON2, are involved in different processes and where interpretations could otherwise be off track.

The biological process described as cell adhesion in fact encompasses three of the terms in the list in Table III (cell adhesion, regulation of cell adhesion and cell-cell adhesion). Other terms associated with adhesion are also altered, for example "integrin mediated signaling pathway" which was up-regulated in the SOM cluster analysis (cluster 4; $\mathrm{z}$ score $=2.35$ ) but not in the global analysis (z score $=$ 1.7). Modifications in the expression of integrins by herpesvirus-infected cells have been described under different experimental conditions and may be related to different aspects of virus physiology [45], Van de Walle et al. [41] have shown, in vitro, that in immune masked monocytes infected with PRV, some of the integrin molecules at the monocyte cell surface, are redistributed, adhere efficiently to the endothelial cells and transmit the virus to them. Interestingly, not all the integrin molecules are redistributed during this process, CD11b and CD18 remain at the cell surface whereas CD11a and CD15 are internalized. According to our microarray results, CD11a expression is up-regulated in PRV-infected HEK 293cells.

Several of the biological process terms are related to ion transport and to potassium transport in particular. Modifications of the electrophysiological properties of membranes have been described in HSV-1 infected neurons [15, 24, 25, 35] and the involvement of ion channels demonstrated in the spontaneous bursting activity observed in the superior cervical ganglion of 
PRV-infected rats [22]. Our results indicate that the potassium transport process was significantly up-regulated (23 genes up-regulated, z score $=3.37$ ) compared to sodium transport, which does not appear in our list of gene ontology terms (Tab. III), even though the expression of some of the genes involved in sodium transport was altered ( 7 genes up-regulated, $\mathrm{z}$ score $=$ 1.3). The few reports that deal with the effect of herpesvirus infection on ion channel activity mainly concern the expression of sodium channel activity [35], however, a recent report by Kramer et al. [21] showed an increase in potassium channel expression during HSV-1 sensory neuron infection in the mouse.

The gene ontology analysis of the infection of HEK-293 cells by the pseudorabies virus has clearly revealed those biological processes which are significantly altered and are of importance either in virus replication or in the host's response to viral attack.

Although Gene Ontology is only a recently developed tool and still suffers from imperfections, several of the processes revealed by the GO analysis have already been described for PRV or other alphaherpes viruses. This would confirm the validity of this approach for the study of virus host interactions.

While this manuscript was being written, Ray and Enquist published their article about the transcriptional response of rat fibroblastic cells to infection by PRV or HSV1 [28]. These authors used a different analytical approach and did not refer to Gene Ontology. However the list of functional classes that they produced contains most of the biological processes specified in our results, again confirming the validity of our analysis.

One aim in this study was to determine whether, a pan genomic microarray analysis would be able to provide reliable information about virus host interactions, in an emergency (for example an emerg- ing zoonosis of viral origin), and with a limited number of samples. Large datasets would not be immediately available in such a situation and the validity of any microarray analyses might, as a result, be weakened. The extensive use of microarray analyses in cancer studies has been useful in identifying the genes or clusters of genes involved in a given pathology but truly robust results have required extensive datasets derived from tens or hundreds of microarray experiments $[32,44]$. Our results suggest that this approach might also be valuable for a more rapid characterization of an emerging virus. However it should be remembered that the PRV infection in our study resulted in a massive alteration of cell physiology and that this probably strengthened our results, due to the large number of genes with altered expression. It will be interesting to test a similar strategy on discrete viruses to see whether this approach is sufficiently robust when the transcription program shows few modifications.

\section{ACKNOWLEDGEMENTS}

This work was supported by grant P3681/5662 from Région Bretagne.

\section{REFERENCES}

[1] Ambagala A.P., Hinkley S., Srikumaran S., An early pseudorabies virus protein downregulates porcine MHC class I expression by inhibition of transporter associated with antigen processing (TAP), J. Immunol. 164 (2000) 93-99.

[2] Berthomme H., Jacquemont B., Epstein A., The pseudorabies virus host-shutoff homolog gene: nucleotide sequence and comparison with alphaherpesvirus protein counterparts, Virology 193 (1993) 1028-1032.

[3] Boldogkoi Z., Bratincsak A., Fodor I., Evaluation of pseudorabies virus as a gene transfer vector and an oncolytic agent for human tumor cells, Anticancer Res. 22 (2002) 2153-2159. 
[4] Bryant H.E., Wadd S.E., Lamond A.I., Silverstein S.J., Clements J.B., Herpes simplex virus IE63 (ICP27) protein interacts with spliceosome-associated protein 145 and inhibits splicing prior to the first catalytic step, J. Virol. 75 (2001) 4376-4385.

[5] Chang Y.E., Laimins L.A., Microarray analysis identifies interferon-inducible genes and Stat-1 as major transcriptional targets of human papillomavirus type 31 , J. Virol. 74 (2000) 4174-4182.

[6] Chen I.H., Sciabica K.S., Sandri-Goldin R.M., ICP27 interacts with the RNA export factor Aly/REF to direct herpes simplex virus type 1 intronless mRNAs to the TAP export pathway, J. Virol. 76 (2002) 1287712889.

[7] Dahlquist K.D., Salomonis N., Vranizan K. Lawlor S.C., Conklin B.R., GenMAPP, a new tool for viewing and analyzing microarray data on biological pathways, Nat. Genet. 31 (2002) 19-20.

[8] Doniger S.W., Salomonis N., Dahlquist K.D., Vranizan K., Lawlor S.C., Conklin B.R., MAPPFinder: using Gene Ontology and GenMAPP to create a global geneexpression profile from microarray data, Genome Biol. 4 (2003) R7.

[9] Elgadi M.M., Hayes C.E., Smiley J.R., The herpes simplex virus vhs protein induces endoribonucleolytic cleavage of target RNAs in cell extracts, J. Virol. 73 (1999) 7153-7164.

[10] Enquist L.W., Husak P.J., Banfield B.W., Smith G.A., Infection and spread of alphaherpesviruses in the nervous system, Adv. Virus Res. 51 (1998) 237-347.

[11] Enquist L.W., Card J.P., Recent advances in the use of neurotropic viruses for circuit analysis, Curr. Opin. Neurobiol. 13 (2003) 603-606.

[12] Everly D.N. Jr., Feng P., Mian I.S., Read G.S., mRNA degradation by the virion host shutoff (Vhs) protein of herpes simplex virus: genetic and biochemical evidence that Vhs is a nuclease, J. Virol. 76 (2002) 8560 8571 .

[13] Feng X., Thompson Y.G., Lewis J.B., Caughman G.B., Expression and function of the equine herpesvirus 1 virion-associated host shutoff homolog, J. Virol. 70 (1996) 8710-8718.

[14] Flemington E.K., Herpesvirus lytic replication and the cell cycle: arresting new developments, J. Virol. 75 (2001) 4475-4481.

[15] Fukuda J., Kurata T., Loss of membrane excitability after herpes simplex virus infec- tion in tissue-cultured nerve cells from adult mammals, Brain Res. 211 (1981) 235-241.

[16] Green M.R., Treisman R., Maniatis T., Transcriptional activation of cloned human beta-globin genes by viral immediate-early gene products, Cell 35 (1983) 137-148.

[17] Guerra S., Lopez-Fernandez L.A., PascualMontano A., Munoz M., Harshman K., Esteban M., Cellular gene expression survey of vaccinia virus infection of human HeLa cells, J. Virol. 77 (2003) 6493-6506.

[18] He Y.W., Li H., Zhang J., Hsu C.L., Lin E., Zhang N., Guo J., Forbush K.A., Bevan M.J., The extracellular matrix protein mindin is a pattern-recognition molecule for microbial pathogens, Nat. Immunol. 5 (2004) 88-97.

[19] Ihara S., Feldman L., Watanabe S., Ben-Porat T., Characterization of the immediate-early functions of pseudorabies virus, Virology 131 (1983) 437-454.

[20] Klupp B.G., Hengartner C.J., Mettenleiter T.C., Enquist L.W., Complete, annotated sequence of the pseudorabies virus genome, J. Virol. 78 (2004) 424-440

[21] Kramer M.F., Cook W.J., Roth F.P., Zhu J., Holman H., Knipe D.M., Coen D.M., Latent herpes simplex virus infection of sensory neurons alters neuronal gene expression, J. Virol. 77 (2003) 9533-9541.

[22] Liao G.S., Maillard M., Kiraly M., Ion channels involved in the presynaptic hyperexcitability induced by herpes virus suis in rat superior cervical ganglion, Neuroscience 41 (1991) 797-807.

[23] Martinez W.M., Spear P.G., Amino acid substitutions in the V domain of nectin-1 (HveC) that impair entry activity for herpes simplex virus types 1 and 2 but not for Pseudorabies virus or bovine herpesvirus 1, J. Virol. 76 (2002) 7255-7262.

[24] Mayer M.L., Selective block of inward but not outward rectification in rat sensory neurones infected with herpes simplex virus, J. Physiol. 375 (1986) 327-338.

[25] Mayer M.L., James M.H., Russell R.J., Kelly J.S., Pasternak C.A., Changes in excitability induced by herpes simplex viruses in rat dorsal root ganglion neurons, J. Neurosci. 6 (1986) 391-402.

[26] Paul P.S., Halbur P., Janke B., Joo H., Nawagitgul P., Singh J., Sorden S., Exogenous porcine viruses, Curr. Top. Microbiol. Immunol. 278 (2003) 125-183.

[27] Paulose-Murphy M., Ha N.K., Xiang C., Chen Y., Gillim L., Yarchoan R., Meltzer 
P., Bittner M., Trent J., Zeichner S., Transcription program of human herpesvirus 8 (kaposi's sarcoma-associated herpesvirus), J. Virol. 75 (2001) 4843-4853.

[28] Ray N., Enquist L.W., Transcriptional response of a common permissive cell type to infection by two diverse alphaherpesviruses, J. Virol. 78 (2004) 3489-3501.

[29] Roizman B., Sears A.E., Herpes simplex viruses and their replication, in: Fields B.N., Knipe D.M., Howley P.M., Chanock T.P., Melnick J.L., Monath T.P., Roizman B., Straus S.E. (Eds.), Fields virology, Vol. 2, Lippincott - Raven, Philadelphia, 1996, pp. 2231-2295.

[30] Sciabica K.S., Dai Q.J., Sandri-Goldin R.M., ICP27 interacts with SRPK1 to mediate HSV splicing inhibition by altering SR protein phosphorylation, EMBO J. 22 (2003) 16081619.

[31] Shaw G., Morse S., Ararat M., Graham F.L., Preferential transformation of human neuronal cells by human adenoviruses and the origin of HEK 293 cells, FASEB J. 16 (2002) 869-871.

[32] Smid M., Dorssers L.C., Jenster G., Venn Mapping: clustering of heterologous microarray data based on the number of co-occurring differentially expressed genes, Bioinformatics 19 (2003) 2065-2071.

[33] Smith G.A., Enquist L.W., Break ins and break outs: viral interactions with the cytoskeleton of Mammalian cells, Annu. Rev. Cell Dev. Biol. 18 (2002) 135-161.

[34] Stingley S.W., Ramirez J.J., Aguilar S.A., Simmen K., Sandri-Goldin R.M., Ghazal P., Wagner E.K., Global analysis of herpes simplex virus type 1 transcription using an oligonucleotide-based DNA microarray, J. Virol. 74 (2000) 9916-9927.

[35] Storey N., Latchman D., Bevan S., Selective internalization of sodium channels in rat dorsal root ganglion neurons infected with herpes simplex virus-1, J. Cell Biol. 158 (2002) 1251-1262.

[36] Taddeo B., Esclatine A., Roizman B., The patterns of accumulation of cellular RNAs in cells infected with a wild-type and a mutant herpes simplex virus 1 lacking the virion host shutoff gene, Proc. Natl. Acad. Sci. USA 99 (2002) 17031-17036.

[37] Taharaguchi S., Kon Y., Yoshino S., Ono E., Impaired development of the cerebellum in transgenic mice expressing the immediateearly protein IE180 of pseudorabies virus, Virology 307 (2003) 243-254.

[38] Tirabassi R.S., Enquist L.W., Role of envelope protein $\mathrm{gE}$ endocytosis in the pseudorabies virus life cycle, J. Virol. 72 (1998) 4571-4579.

[39] Tusher V.G., Tibshirani R., Chu G., Significance analysis of microarrays applied to the ionizing radiation response, Proc. Natl. Acad. Sci. USA 98 (2001) 5116-5121.

[40] Tzarfati-Majar V., Burstyn-Cohen T., Klar A., F-spondin is a contact-repellent molecule for embryonic motor neurons, Proc. Natl. Acad. Sci. USA 98 (2001) 4722-4727.

[41] Van de Walle G.R., Favoreel H.W., Nauwynck H.J., Mettenleiter T.C., Pensaert M.B., Transmission of pseudorabies virus from immune-masked blood monocytes to endothelial cells, J. Gen. Virol. 84 (2003) 629-637.

[42] Wang D., Coscoy L., Zylberberg M., Avila P.C., Boushey H.A., Ganem D., DeRisi J.L., Microarray-based detection and genotyping of viral pathogens, Proc. Natl. Acad. Sci. USA 99 (2002) 15687-15692.

[43] Wang D., Urisman A., Liu Y.T., Springer M., Ksiazek T.G., Erdman D.D., Mardis E.R., Hickenbotham M., Magrini V., Eldred J., Latreille J.P., Wilson R.K., Ganem D., DeRisi J.L., Viral discovery and sequence recovery using DNA Microarrays, PLoS Biol. 1 (2003) E2.

[44] Wang J., Bo T.H., Jonassen I., Myklebost O., Hovig E., Tumor classification and marker gene prediction by feature selection and fuzzy c-means clustering using microarray data, BMC Bioinformatics 4 (2003) 60.

[45] Warren A.P., Owens C.N., Borysiewicz L.K., Patel K., Down-regulation of integrin alpha 1 /beta 1 expression and association with cell rounding in human cytomegalovirusinfected fibroblasts, J. Gen. Virol. 75 (1994) 3319-3325. 


\section{APPENDIX}

Table III. Main biological processes altered during the PRV lytic infection of HEK-293.

\begin{tabular}{|c|c|c|c|c|c|c|}
\hline Path & GOID & GO name & $\begin{array}{c}\text { Number } \\
\text { changed } \\
\text { local }\end{array}$ & $\begin{array}{c}\text { Number } \\
\text { measured } \\
\text { local }\end{array}$ & $\begin{array}{l}\text { Number } \\
\text { GO local }\end{array}$ & $\begin{array}{l}\text { Number in } \\
Z \text { Score }\end{array}$ \\
\hline \multicolumn{2}{|c|}{ Up-regulated biological process } & & 372 & & & \\
\hline 0.0 .2 .0 & 7154 & cell communication & 2 & 11 & 27 & 3.252 \\
\hline 0.0 .2 .0 .0 & 7155 & cell adhesion & 43 & 226 & 466 & 4.476 \\
\hline $0.0 .2 \cdot 0.0 .2$ & 16337 & cell-cell adhesion & 4 & 15 & 29 & 2.493 \\
\hline $0.0 \cdot 2 \cdot 0.0 .5$ & 30155 & Regulation of cell adhesion & 3 & 5 & 6 & 2.926 \\
\hline 0.0 .2 .0 .2 & 7267 & cell-cell signaling & 30 & 187 & 288 & 2.418 \\
\hline $0.0 .2 \cdot 0.7 \cdot 0.3 .5 .0 .1 .3$ & 45761 & $\begin{array}{l}\text { Regulation of adenylate } \\
\text { cyclase activity }\end{array}$ & 0 & 0 & 0 & 2.477 \\
\hline $0.0 \cdot 2 \cdot 0 \cdot 7 \cdot 0.3 \cdot 5 \cdot 0.1 \cdot 3 \cdot 0$ & 7194 & $\begin{array}{l}\text { Negative regulation of } \\
\text { adenylate cyclase activity }\end{array}$ & 4 & 11 & 14 & 2.477 \\
\hline 0.0 .2 .4 .2 & 6936 & muscle contraction & 14 & 51 & 72 & 2.277 \\
\hline 0.0 .3 & 7275 & Development & 53 & 284 & 503 & 4.413 \\
\hline 0.0 .3 .12 & 9653 & Morphogenesis & 0 & 1 & 3 & 4.097 \\
\hline 0.0 .3 .12 .8 & 9887 & Organogenesis & 0 & 0 & 1 & 4.171 \\
\hline 0.0 .3 .12 .8 .1 & 1568 & blood vessel development & 0 & 0 & 0 & 2.85 \\
\hline $0.0 .3 \cdot 12.8 .1 .0$ & 1525 & Angiogenesis & 7 & 21 & 27 & 2.85 \\
\hline 0.0 .3 .12 .8 .19 & 7399 & Neurogenesis & 25 & 149 & 223 & 3.068 \\
\hline 0.0 .3 .12 .8 .19 .2 & 7417 & $\begin{array}{l}\text { central nervous system } \\
\text { development }\end{array}$ & 9 & 41 & 63 & 2.295 \\
\hline 0.0 .4 .90 & 7345 & $\begin{array}{l}\text { Embryogenesis and } \\
\text { morphogenesis }\end{array}$ & 16 & 77 & 117 & 2.363 \\
\hline $0.0 .5 \cdot 3 \cdot 10.17 .3 .1$ & 30001 & metal ion transport & 0 & 11 & 25 & 2.491 \\
\hline $0.0 .5 \cdot 3 \cdot 10.17 .3 \cdot 1.4$ & 6813 & Potassium ion transport & 18 & 82 & 180 & 2.767 \\
\hline $0.0 .5 \cdot 3 \cdot 10.22$ & 6836 & Neurotransmitter transport & 5 & 18 & 36 & 2.069 \\
\hline 0.0 .5 .9 & 7586 & Digestion & 7 & 27 & 54 & 2.107 \\
\hline 0.0 .5 .15 & 7599 & Hemostasis & 1 & 3 & 7 & 2.555 \\
\hline 0.0 .5 .15 .0 & 7596 & blood coagulation & 12 & 54 & 73 & 2.363 \\
\hline 0.0 .5 .20 .8 & 9056 & Catabolism & 0 & 1 & 1 & 2.769 \\
\hline 0.0 .5 .20 .8 .22 .1 .3 .1 & 30574 & collagen catabolism & 4 & 10 & 17 & 2.715 \\
\hline 0.0 .5 .20 .25 .11 .0 & 45449 & Regulation of transcription & 0 & 2 & 4 & 2.049 \\
\hline $0.0 .5 \cdot 20.25 .11 .0 .2$ & 6355 & $\begin{array}{l}\text { Regulation of transcription } \backslash \text {, } \\
\text { DNA-dependent }\end{array}$ & 99 & 685 & 1727 & 2.138 \\
\hline $0.0 .5 \cdot 20.35 .14 .5$ & 18149 & peptide cross-linking & 3 & 7 & 10 & 2.503 \\
\hline $0.0 .5 \cdot 34 \cdot 2 \cdot 1.6$ & 9636 & Response to toxin & 4 & 10 & 18 & 2.715 \\
\hline $0.0 .5 \cdot 34.3 \cdot 1.3 .7 .0$ & 19730 & $\begin{array}{l}\text { Antimicrobial humoral } \\
\text { response }\end{array}$ & 0 & 0 & 0 & 2.051 \\
\hline $0.0 .5 .34 .3 \cdot 1.3 .7 .0 .2$ & 6960 & $\begin{array}{l}\text { Antimicrobial humoral } \\
\text { response (sensu Invertebrata) }\end{array}$ & 14 & 67 & 90 & 2.051 \\
\hline \multicolumn{3}{|c|}{ Down-regulated Biological Process } & 1141 & & & \\
\hline $0.0 \cdot 2 \cdot 0 \cdot 7 \cdot 2 \cdot 13$ & 7264 & $\begin{array}{l}\text { small GTPase mediated } \\
\text { signal transduction }\end{array}$ & 30 & 95 & 224 & 3.326 \\
\hline 0.0 .2 .3 & 8151 & $\begin{array}{l}\text { cell growth and/or } \\
\text { maintenance }\end{array}$ & 21 & 133 & 249 & 3.925 \\
\hline 0.0 .2 .3 .4 & 16043 & $\begin{array}{l}\text { cell organization and } \\
\text { biogenesis }\end{array}$ & 0 & 0 & 0 & 5.899 \\
\hline 0.0 .2 .3 .4 .5 & 7028 & $\begin{array}{l}\text { Cytoplasm organization and } \\
\text { biogenesis }\end{array}$ & 0 & 0 & 0 & 6.045 \\
\hline $0.0 \cdot 2 \cdot 3.4 .5 .2$ & 6996 & $\begin{array}{l}\text { Organelle organization and } \\
\text { biogenesis }\end{array}$ & 1 & 2 & 3 & 5.285 \\
\hline 0.0 .2 .3 .4 .5 .2 .0 & 7010 & $\begin{array}{l}\text { Cytoskeleton organization } \\
\text { and biogenesis }\end{array}$ & 4 & 19 & 44 & 2.995 \\
\hline $0.0 .2 \cdot 3 \cdot 4 \cdot 5 \cdot 2 \cdot 0.1$ & 7016 & Cytoskeletal anchoring & 3 & 4 & 10 & 2.905 \\
\hline $0.0 \cdot 2 \cdot 3 \cdot 4 \cdot 5 \cdot 2 \cdot 0.5$ & 7017 & Microtubule-based process & 1 & 5 & 9 & 3.157 \\
\hline 0.0 .2 .3 .4 .5 .2 .0 .5 .0 & 226 & $\begin{array}{l}\text { Microtubule cytoskeleton } \\
\text { organization and biogenesis }\end{array}$ & 2 & 5 & 13 & 3.08 \\
\hline 0.0 .2 .3 .4 .5 .2 .1 & 7032 & $\begin{array}{l}\text { Endosome organization and } \\
\text { biogenesis }\end{array}$ & 0 & 0 & 1 & 3.374 \\
\hline $0.0 \cdot 2 \cdot 3 \cdot 4 \cdot 5 \cdot 2 \cdot 1.0$ & 16197 & Endosome transport & 2 & 4 & 5 & 3.374 \\
\hline 0.0 .2 .3 .4 .5 .2 .2 & 7029 & $\begin{array}{l}\text { ER organization and } \\
\text { biogenesis }\end{array}$ & 0 & 0 & 0 & 3.199 \\
\hline $0.0 \cdot 2 \cdot 3 \cdot 4 \cdot 5 \cdot 2.2 .0$ & 45047 & protein-ER targeting & 0 & 0 & 0 & 3.199 \\
\hline 0.0 .2 .3 .4 .5 .2 .2 .0 .0 & 6613 & $\begin{array}{l}\text { Cotranslational membrane } \\
\text { targeting }\end{array}$ & 4 & 6 & 7 & 3.033 \\
\hline 0.0 .2 .3 .4 .5 .2 .5 & 7040 & $\begin{array}{l}\text { Lysosome organization and } \\
\text { biogenesis }\end{array}$ & 1 & 2 & 3 & 2.289 \\
\hline
\end{tabular}


Table III. Continued.

\begin{tabular}{|c|c|c|c|c|c|c|}
\hline Path & GOID & GO name & $\begin{array}{l}\text { Number } \\
\text { changed } \\
\text { local }\end{array}$ & $\begin{array}{l}\text { Number } \\
\text { measured } \\
\text { local }\end{array}$ & $\begin{array}{l}\text { Number } \\
\text { GO local }\end{array}$ & $\begin{array}{l}\text { Number in } \\
\text { Z Score }\end{array}$ \\
\hline 0.0 .2 .3 .4 .5 .3 & 42254 & $\begin{array}{l}\text { Ribosome biogenesis and } \\
\text { assembly }\end{array}$ & 0 & 0 & 0 & 3.623 \\
\hline 0.0 .2 .3 .4 .5 .3 .1 & 7046 & Ribosome biogenesis & 3 & 4 & 8 & 3.623 \\
\hline 0.0 .2 .3 .4 .5 .3 .1 .3 & 6364 & rRNA processing & 7 & 15 & 28 & 2.804 \\
\hline 0.0 .2 .3 .4 .8 & 6997 & $\begin{array}{l}\text { nuclear organization and } \\
\text { biogenesis }\end{array}$ & 0 & 2 & 3 & 2.804 \\
\hline 0.0 .2 .3 .4 .8 .0 & 7001 & $\begin{array}{l}\text { Chromosome organization } \\
\text { and biogenesis (sensu } \\
\text { Eukarya) }\end{array}$ & 7 & 20 & 76 & 2.941 \\
\hline 0.0 .2 .3 .4 .8 .0 .0 & 6325 & $\begin{array}{l}\text { Establishment and/or } \\
\text { maintenance of chromatin } \\
\text { architecture }\end{array}$ & 1 & 6 & 16 & 2.38 \\
\hline 0.0 .2 .3 .4 .8 .0 .0 .1 .0 & 16569 & $\begin{array}{l}\text { Covalent chromatin } \\
\text { modification }\end{array}$ & 0 & 0 & 0 & 2.385 \\
\hline $0.0 \cdot 2 \cdot 3.4 .8 .0 .0 .1 .0 .0$ & 16570 & histone modification & 0 & 0 & 0 & 2.385 \\
\hline 0.0 .2 .3 .4 .8 .0 .0 .1 .0 .0 .1 & 16575 & histone deacetylation & 3 & 4 & 7 & 2.905 \\
\hline 0.0 .2 .3 .5 & 8283 & cell proliferation & 23 & 162 & 239 & 2.471 \\
\hline 0.0 .2 .3 .5 .0 & 7049 & cell cycle & 27 & 77 & 156 & 5.118 \\
\hline 0.0 .2 .3 .5 .0 .1 & 67 & $\begin{array}{l}\text { DNA replication and } \\
\text { chromosome cycle }\end{array}$ & 1 & 5 & 6 & 6.18 \\
\hline $0.0 \cdot 2 \cdot 3.5 \cdot 0.1 .1$ & 30261 & Chromosome condensation & 0 & 0 & 0 & 2.061 \\
\hline 0.0 .2 .3 .5 .0 .1 .2 & 7059 & Chromosome segregation & 5 & 9 & 13 & 4.134 \\
\hline 0.0 .2 .3 .5 .0 .1 .2 .2 & 70 & $\begin{array}{l}\text { mitotic chromosome } \\
\text { segregation }\end{array}$ & 4 & 6 & 8 & 3.033 \\
\hline 0.0 .2 .3 .5 .0 .3 & 279 & M phase & 0 & 1 & 3 & 5.298 \\
\hline $0.0 \cdot 2 \cdot 3 \cdot 5 \cdot 0.3 .0$ & 87 & M phase of mitotic cell cycle & 1 & 2 & 3 & 6.306 \\
\hline 0.0 .2 .3 .5 .0 .3 .0 .1 & 7067 & Mitosis & 28 & 55 & 78 & 6.201 \\
\hline $0.0 .2 \cdot 3 \cdot 5 \cdot 0.3 \cdot 0.1 .1 .4$ & 70 & $\begin{array}{l}\text { mitotic chromosome } \\
\text { segregation }\end{array}$ & 4 & 6 & 8 & 3.033 \\
\hline $0.0 \cdot 2 \cdot 3 \cdot 5 \cdot 0.3 \cdot 0.1 .7$ & 7052 & mitotic spindle assembly & 3 & 4 & 8 & 3.6 \\
\hline $0.0 .2 \cdot 3.5 .0 .3 .1$ & 72 & $\begin{array}{l}\text { M-phase specific microtubule } \\
\text { process }\end{array}$ & 0 & 0 & 0 & 2.857 \\
\hline $0.0 \cdot 2 \cdot 3 \cdot 5 \cdot 0.3 .1 .2$ & 7051 & spindle assembly & 0 & 0 & 0 & 3.6 \\
\hline $0.0 .2 \cdot 3 \cdot 5 \cdot 0.3 \cdot 1.2 .1$ & 7052 & mitotic spindle assembly & 3 & 4 & 8 & 3.6 \\
\hline $0.0 \cdot 2 \cdot 3 \cdot 5 \cdot 0.4$ & 278 & mitotic cell cycle & 0 & 0 & 0 & 8.319 \\
\hline 0.0 .2 .3 .5 .0 .4 .1 & 82 & $\begin{array}{l}\text { G1/S transition of mitotic cell } \\
\text { cycle }\end{array}$ & 5 & 8 & 14 & 3.147 \\
\hline 0.0 .2 .3 .5 .0 .4 .3 & 86 & $\begin{array}{l}\text { G2/M transition of mitotic } \\
\text { cell cycle }\end{array}$ & 1 & 2 & 6 & 2.087 \\
\hline 0.0 .2 .3 .5 .0 .4 .8 & 84 & S phase of mitotic cell cycle & 0 & 1 & 2 & 5 \\
\hline $0.0 \cdot 2 \cdot 3 \cdot 5 \cdot 0.4 .8 .0$ & 6260 & DNA replication & 21 & 50 & 94 & 5 \\
\hline 0.0 .2 .3 .5 .0 .4 .8 .0 .3 & 6261 & $\begin{array}{l}\text { DNA dependent DNA } \\
\text { replication }\end{array}$ & 3 & 8 & 8 & 3.602 \\
\hline $0.0 \cdot 2 \cdot 3 \cdot 5 \cdot 0.4 \cdot 8 \cdot 0.3 .2$ & 6270 & DNA replication initiation & 5 & 12 & 22 & 2.061 \\
\hline $0.0 \cdot 2 \cdot 3 \cdot 5 \cdot 0 \cdot 4 \cdot 8 \cdot 0.3 \cdot 10$ & 6275 & $\begin{array}{l}\text { Regulation of DNA } \\
\text { replication }\end{array}$ & 2 & 2 & 3 & 2.905 \\
\hline 0.0 .2 .3 .5 .0 .6 & 74 & Regulation of cell cycle & 23 & 107 & 179 & 2.348 \\
\hline 0.0 .2 .3 .5 .1 & 910 & Cytokinesis & 19 & 46 & 94 & 3.87 \\
\hline 0.0 .2 .3 .10 & 6810 & Transport & 52 & 290 & 696 & 2.347 \\
\hline 0.0 .2 .3 .10 .15 & 6818 & Hydrogen transport & 0 & 0 & 0 & 6.305 \\
\hline 0.0 .2 .3 .10 .15 .1 & 15992 & proton transport & 21 & 39 & 82 & 6.055 \\
\hline 0.0 .2 .3 .10 .16 & 46907 & Intracellular transport & 0 & 0 & 0 & 7.121 \\
\hline 0.0 .2 .3 .10 .16 .3 & 16197 & Endosome transport & 2 & 4 & 5 & 3.374 \\
\hline $0.0 \cdot 2 \cdot 3 \cdot 10.16 .13$ & 6913 & Nucleocytoplasmic transport & 1 & 1 & 1 & 4.363 \\
\hline 0.0 .2 .3 .10 .16 .13 .4 & 6405 & RNA-nucleus export & 2 & 2 & 2 & 4.109 \\
\hline 0.0 .2 .3 .10 .16 .13 .4 .0 & 6406 & mRNA-nucleus export & 4 & 6 & 14 & 3.033 \\
\hline $0.0 \cdot 2 \cdot 3 \cdot 10.32$ & 15031 & protein transport & 5 & 18 & 36 & 6.876 \\
\hline 0.0 .2 .3 .10 .32 .2 & 6886 & Intracellular protein transport & 63 & 173 & 294 & 6.749 \\
\hline 0.0 .2 .3 .10 .32 .2 .3 & 6605 & protein targeting & 11 & 34 & 44 & 4.199 \\
\hline 0.0 .2 .3 .10 .32 .2 .3 .1 & 45047 & protein-ER targeting & 0 & 0 & 0 & 3.199 \\
\hline 0.0 .2 .3 .10 .32 .2 .3 .1 .0 & 6613 & Cotranslational membrane targeting & 4 & 6 & 7 & 3.033 \\
\hline 0.0 .2 .3 .10 .32 .2 .3 .4 & 6612 & protein-membrane targeting & 2 & 2 & 2 & 4.109 \\
\hline
\end{tabular}


Table III. Continued.

\begin{tabular}{|c|c|c|c|c|c|c|}
\hline Path & GOID & GO name & $\begin{array}{c}\text { Number } \\
\text { changed } \\
\text { local }\end{array}$ & $\begin{array}{c}\text { Number } \\
\text { measured } \\
\text { local }\end{array}$ & $\begin{array}{l}\text { Number } \\
\text { GO local }\end{array}$ & $\begin{array}{l}\text { Number in } \\
\text { Z Score }\end{array}$ \\
\hline $0.0 .2 .3 \cdot 10.32 .2 .3 .7$ & 6606 & protein-nucleus import & 4 & 11 & 14 & 2.908 \\
\hline 0.0 .2 .3 .10 .32 .2 .3 .7 .2 & 59 & $\begin{array}{l}\text { protein-nucleus import } \backslash \text {, } \\
\text { docking }\end{array}$ & 7 & 13 & 18 & 3.276 \\
\hline $0.0 \cdot 2 \cdot 3 \cdot 10.36$ & 16192 & vesicle-mediated transport & 9 & 23 & 36 & 2.818 \\
\hline $0.0 .2 .3 \cdot 10.36 .4$ & 6887 & Exocytosis & 4 & 12 & 25 & 2.152 \\
\hline 0.0 .4 .133 & 6371 & mRNA splicing & 15 & 32 & 46 & 4.131 \\
\hline 0.0 .5 & 7582 & Physiological processes & 0 & 10 & 18 & 2.156 \\
\hline 0.0 .5 .20 & 8152 & Metabolism & 34 & 185 & 456 & 4.147 \\
\hline 0.0 .5 .20 .0 .16 .0 .0 & 6695 & Cholesterol biosynthesis & 6 & 14 & 17 & 2.139 \\
\hline $0.0 .5 \cdot 20.2 .9 .12$ & 9069 & $\begin{array}{l}\text { serine family amino acid } \\
\text { metabolism }\end{array}$ & 0 & 0 & 0 & 3.239 \\
\hline $0.0 .5 \cdot 20.2 .9 .12 .1$ & 6544 & glycine metabolism & 0 & 1 & 5 & 2.905 \\
\hline $0.0 .5 \cdot 20.2 \cdot 9 \cdot 12.3 .2$ & 6564 & L-serine biosynthesis & 4 & 7 & 11 & 2.628 \\
\hline $0.0 .5 \cdot 20.2 .15 .11$ & 6595 & Polyamine metabolism & 1 & 1 & 2 & 2.628 \\
\hline $0.0 .5 \cdot 20.5 .12$ & 46138 & $\begin{array}{l}\text { Coenzymes and prosthetic } \\
\text { group biosynthesis }\end{array}$ & 0 & 0 & 0 & 4.605 \\
\hline $0.0 .5 \cdot 20.5 .22$ & 9059 & Macromolecule biosynthesis & 0 & 0 & 0 & 4.498 \\
\hline $0.0 .5 \cdot 20.5 .22 .3$ & 6412 & protein biosynthesis & 42 & 132 & 243 & 4.498 \\
\hline 0.0 .5 .20 .5 .22 .3 .18 & 6417 & $\begin{array}{l}\text { Regulation of protein } \\
\text { biosynthesis }\end{array}$ & 6 & 12 & 18 & 2.562 \\
\hline $0.0 .5 \cdot 20.5 .22 .3 .19$ & 6445 & Regulation of translation & 5 & 12 & 21 & 4.591 \\
\hline 0.0 .5 .20 .5 .22 .3 .19 .7 & 6446 & $\begin{array}{l}\text { Regulation of translational } \\
\text { initiation }\end{array}$ & 13 & 22 & 33 & 4.692 \\
\hline $0.0 .5 \cdot 20.5 .27$ & 9165 & Nucleotide biosynthesis & 2 & 6 & 12 & 5.616 \\
\hline 0.0 .5 .20 .5 .27 .4 & 9142 & $\begin{array}{l}\text { Nucleoside triphosphate } \\
\text { biosynthesis }\end{array}$ & 2 & 2 & 3 & 6.66 \\
\hline 0.0 .5 .20 .5 .27 .4 .1 & 9145 & $\begin{array}{l}\text { purine nucleoside } \\
\text { triphosphate biosynthesis }\end{array}$ & 0 & 0 & 0 & 6.66 \\
\hline 0.0 .5 .20 .5 .27 .4 .1 .1 & 9206 & $\begin{array}{l}\text { purine ribonucleoside } \\
\text { triphosphate biosynthesis }\end{array}$ & 0 & 0 & 0 & 6.66 \\
\hline $0.0 .5 \cdot 20.5 \cdot 27.4 \cdot 1.1 .1$ & 6754 & ATP biosynthesis & 11 & 14 & 22 & 6.15 \\
\hline 0.0 .5 .20 .5 .27 .4 .1 .1 .2 & 6183 & GTP biosynthesis & 5 & 9 & 14 & 2.857 \\
\hline $0.0 .5 \cdot 20.5 \cdot 27.4 .3$ & 9201 & $\begin{array}{l}\text { Ribonucleoside triphosphate } \\
\text { biosynthesis }\end{array}$ & 0 & 0 & 0 & 6.66 \\
\hline $0.0 .5 \cdot 20.5 .27 .4 .3 .1$ & 9209 & $\begin{array}{l}\text { Pyrimidine ribonucleoside } \\
\text { triphosphate biosynthesis }\end{array}$ & 0 & 0 & 0 & 2.289 \\
\hline $0.0 .5 \cdot 20.5 \cdot 27 \cdot 4 \cdot 3 \cdot 1.0$ & 6241 & CTP biosynthesis & 4 & 8 & 12 & 2.289 \\
\hline $0.0 .5 \cdot 20.5 \cdot 27.4 .3 .1 .2$ & 6228 & UTP biosynthesis & 4 & 8 & 12 & 2.289 \\
\hline $0.0 .5 \cdot 20.5 \cdot 27.5$ & 6164 & $\begin{array}{l}\text { purine nucleotide } \\
\text { biosynthesis }\end{array}$ & 2 & 3 & 10 & 6.497 \\
\hline 0.0 .5 .20 .5 .27 .5 .4 & 9152 & $\begin{array}{l}\text { purine ribonucleotide } \\
\text { biosynthesis }\end{array}$ & 1 & 1 & 1 & 6.135 \\
\hline 0.0 .5 .20 .5 .27 .6 & 6221 & $\begin{array}{l}\text { Pyrimidine nucleotide } \\
\text { biosynthesis }\end{array}$ & 1 & 2 & 6 & 3.548 \\
\hline $0.0 .5 \cdot 20.5 .27 .6 .4$ & 9220 & $\begin{array}{l}\text { Pyrimidine ribonucleotide } \\
\text { biosynthesis }\end{array}$ & 1 & 1 & 1 & 3.374 \\
\hline $0.0 .5 \cdot 20.5 .27 .8$ & 9260 & Ribonucleotide biosynthesis & 0 & 0 & 0 & 6.759 \\
\hline 0.0 .5 .20 .5 .27 .8 .0 & 9152 & $\begin{array}{l}\text { purine ribonucleotide } \\
\text { biosynthesis }\end{array}$ & 1 & 1 & 1 & 6.135 \\
\hline 0.0 .5 .20 .5 .27 .8 .4 & 9201 & $\begin{array}{l}\text { Ribonucleoside triphosphate } \\
\text { biosynthesis }\end{array}$ & 0 & 0 & 0 & 6.66 \\
\hline 0.0 .5 .20 .5 .35 .18 & 6417 & $\begin{array}{l}\text { Regulation of protein } \\
\text { biosynthesis }\end{array}$ & 6 & 12 & 18 & 2.562 \\
\hline 0.0 .5 .20 .6 .6 & 16052 & Carbohydrate catabolism & 0 & 0 & 0 & 2.741 \\
\hline 0.0 .5 .20 .6 .6 .7 & 46365 & Monosaccharide catabolism & 0 & 0 & 0 & 3.026 \\
\hline $0.0 .5 \cdot 20.6 \cdot 6.7 .0$ & 19320 & hexose catabolism & 0 & 0 & 0 & 2.717 \\
\hline $0.0 .5 \cdot 20 \cdot 6 \cdot 6 \cdot 7 \cdot 0.4$ & 6007 & glucose catabolism & 0 & 2 & 2 & 2.836 \\
\hline $0.0 .5 \cdot 20 \cdot 6 \cdot 6 \cdot 7 \cdot 0.4 .0$ & 6096 & Glycolysis & 12 & 29 & 55 & 3.169 \\
\hline 0.0 .5 .20 .6 .12 .6 & 6099 & Tricarboxylic acid cycle & 10 & 17 & 29 & 4.276 \\
\hline 0.0 .5 .20 .8 .22 .1 .3 .9 .3 & 6511 & $\begin{array}{l}\text { Ubiquitin-dependent protein } \\
\text { catabolism }\end{array}$ & 30 & 67 & 140 & 5.664 \\
\hline 0.0 .5 .20 .11 & 6118 & electron transport & 44 & 187 & 511 & 2.708 \\
\hline 0.0 .5 .20 .11 .5 & 42773 & $\begin{array}{l}\text { ATP synthesis coupled } \\
\text { electron transport }\end{array}$ & 0 & 0 & 0 & 3.718 \\
\hline
\end{tabular}


Table III. Continued.

\begin{tabular}{|c|c|c|c|c|c|c|}
\hline Path & GOID & GO name & $\begin{array}{c}\text { Number } \\
\text { changed } \\
\text { local }\end{array}$ & $\begin{array}{l}\text { Number } \\
\text { measured } \\
\text { local }\end{array}$ & $\begin{array}{l}\text { Number } \\
\text { GO local }\end{array}$ & $\begin{array}{l}\text { Number in } \\
\text { Z Score }\end{array}$ \\
\hline 0.0 .5 .20 .11 .5 .1 & 42775 & $\begin{array}{l}\text { ATP synthesis coupled } \\
\text { electron transport (sensu } \\
\text { Eukarya) }\end{array}$ & 0 & 0 & 0 & 3.718 \\
\hline 0.0 .5 .20 .11 .5 .1 .1 & 6120 & $\begin{array}{l}\text { Mitochondrial electron } \\
\text { transport, NADH to } \\
\text { ubiquinone }\end{array}$ & 8 & 14 & 36 & 3.718 \\
\hline 0.0 .5 .20 .12 & 6091 & energy pathways & 23 & 73 & 89 & 4.018 \\
\hline 0.0 .5 .20 .25 .0 & 6259 & DNA metabolism & 2 & 16 & 23 & 4.872 \\
\hline $0.0 .5 \cdot 20.25 .0 .4 .0$ & 6325 & $\begin{array}{l}\text { Establishment and/or } \\
\text { maintenance of chromatin } \\
\text { architecture }\end{array}$ & 1 & 6 & 16 & 2.38 \\
\hline 0.0 .5 .20 .25 .0 .4 .0 .1 .0 & 16569 & $\begin{array}{l}\text { covalent chromatin } \\
\text { modification }\end{array}$ & 0 & 0 & 0 & 2.385 \\
\hline 0.0 .5 .20 .25 .0 .4 .0 .1 .0 .0 & 16570 & histone modification & 0 & 0 & 0 & 2.385 \\
\hline 0.0 .5 .20 .25 .0 .4 .0 .1 .0 .0 .1 & 16575 & histone deacetylation & 3 & 4 & 7 & 2.905 \\
\hline $0.0 .5 \cdot 20.25 .0 .7$ & 6281 & DNA repair & 20 & 73 & 116 & 3.121 \\
\hline $0.0 .5 \cdot 20.25 .0 .7 .5$ & 6302 & double-strand break repair & 4 & 4 & 8 & 3.033 \\
\hline $0.0 .5 \cdot 20.25 \cdot 0.7 .12$ & 6301 & Postreplication repair & 3 & 4 & 4 & 2.905 \\
\hline $0.0 .5 \cdot 20.25 .10$ & 16070 & RNA metabolism & 0 & 2 & 3 & 7.391 \\
\hline 0.0 .5 .20 .25 .10 .3 & 6396 & RNA processing & 14 & 37 & 67 & 7.739 \\
\hline 0.0 .5 .20 .25 .10 .3 .0 & 6397 & mRNA processing & 9 & 29 & 44 & 6.924 \\
\hline $0.0 .5 \cdot 20.25 \cdot 10.3 .3$ & 8380 & RNA splicing & 4 & 7 & 13 & 7.674 \\
\hline $0.0 .5 \cdot 20.25 \cdot 10 \cdot 3 \cdot 3.1$ & 375 & $\begin{array}{l}\text { RNA splicing } \backslash \text {, via } \\
\text { transesterification reactions }\end{array}$ & 0 & 0 & 0 & 7.961 \\
\hline 0.0 .5 .20 .25 .10 .3 .3 .1 .0 & 377 & $\begin{array}{l}\text { RNA splicing } \backslash \text {, via } \\
\text { transesterification reactions } \\
\text { with bulged adenosine as } \\
\text { nucleophile }\end{array}$ & 0 & 0 & 0 & 7.961 \\
\hline $0.0 .5 \cdot 20.25 .10 .3 .3 .1 .0 .2$ & 398 & $\begin{array}{l}\text { nuclear mRNA splicing } \backslash \text {, via } \\
\text { spliceosome }\end{array}$ & 27 & 49 & 71 & 7.961 \\
\hline $0.0 .5 \cdot 20.25 .10 .3 \cdot 3 \cdot 1 \cdot 0.2 .6$ & 245 & Spliceosome assembly & 6 & 8 & 13 & 5.419 \\
\hline $0.0 .5 \cdot 20.25 \cdot 10.3 .3 \cdot 1 \cdot 0.2 .6 .1$ & 6376 & mRNA splice site selection & 4 & 5 & 6 & 3.536 \\
\hline $0.0 .5 \cdot 20.25 \cdot 10.3 .5$ & 6364 & rRNA processing & 7 & 15 & 28 & 2.804 \\
\hline 0.0 .5 .20 .25 .11 .1 .3 & 6354 & RNA elongation & 3 & 4 & 6 & 2.905 \\
\hline $0.0 .5 \cdot 20.29$ & 6119 & Oxidative phosphorylation & 1 & 1 & 4 & 4.651 \\
\hline $0.0 .5 \cdot 20.35$ & 19538 & protein metabolism & 2 & 10 & 15 & 3.033 \\
\hline 0.0 .5 .20 .35 .9 & 6412 & protein biosynthesis & 42 & 132 & 243 & 4.498 \\
\hline 0.0 .5 .20 .35 .9 .18 & 6417 & $\begin{array}{l}\text { Regulation of protein } \\
\text { biosynthesis }\end{array}$ & 6 & 12 & 18 & 2.562 \\
\hline 0.0 .5 .20 .35 .9 .19 & 6445 & Regulation of translation & 5 & 12 & 21 & 4.591 \\
\hline 0.0 .5 .20 .35 .9 .19 .7 & 6446 & $\begin{array}{l}\text { Regulation of translational } \\
\text { initiation }\end{array}$ & 13 & 22 & 33 & 4.692 \\
\hline 0.0 .5 .20 .35 .9 .29 & 6413 & Translational initiation & 4 & 17 & 31 & 3.907 \\
\hline 0.0 .5 .20 .35 .10 .3 .9 & 19941 & $\begin{array}{l}\text { Modification-dependent } \\
\text { protein catabolism }\end{array}$ & 0 & 0 & 0 & 5.664 \\
\hline $0.0 .5 \cdot 20.35 .10 .3 .9 .3$ & 6511 & $\begin{array}{l}\text { Ubiquitin-dependent protein } \\
\text { catabolism }\end{array}$ & 30 & 67 & 140 & 5.664 \\
\hline $0.0 .5 \cdot 20.35 .11 .2$ & 6462 & $\begin{array}{l}\text { protein complex assembly } \backslash \text {, } \\
\text { multichaperone pathway }\end{array}$ & 2 & 4 & 4 & 2.628 \\
\hline $0.0 .5 \cdot 20.35 .12$ & 6457 & protein folding & 26 & 74 & 151 & 3.689 \\
\hline 0.0 .5 .20 .35 .14 .19 .0 & 16575 & histone deacetylation & 3 & 4 & 7 & 2.905 \\
\hline $0.0 .5 \cdot 20.35 .14 .61$ & 6512 & Ubiquitin cycle & 16 & 47 & 114 & 2.633 \\
\hline 0.0 .5 .20 .35 .16 & 6605 & protein targeting & 11 & 34 & 44 & 4.199 \\
\hline 0.0 .5 .20 .35 .16 .1 & 45047 & protein-ER targeting & 0 & 0 & 0 & 3.199 \\
\hline 0.0 .5 .20 .35 .16 .1 .0 & 6613 & $\begin{array}{l}\text { Cotranslational membrane } \\
\text { targeting }\end{array}$ & 4 & 6 & 7 & 3.033 \\
\hline 0.0 .5 .20 .35 .16 .4 & 6612 & protein-membrane targeting & 2 & 2 & 2 & 4.109 \\
\hline 0.0 .5 .20 .35 .16 .7 & 6606 & protein-nucleus import & 4 & 11 & 14 & 2.908 \\
\hline 0.0 .5 .20 .35 .16 .7 .2 & 59 & $\begin{array}{l}\text { protein-nucleus import } \backslash \text {, } \\
\text { docking }\end{array}$ & 7 & 13 & 18 & 3.276 \\
\hline 0.0 .5 .33 & 9719 & $\begin{array}{l}\text { Response to endogenous } \\
\text { stimulus }\end{array}$ & 0 & 0 & 0 & 3.054 \\
\hline 0.0 .5 .33 .2 & 6974 & $\begin{array}{l}\text { Response to DNA damage } \\
\text { stimulus }\end{array}$ & 1 & 5 & 11 & 3.054 \\
\hline 0.0 .5 .33 .2 .3 & 6281 & DNA repair & 20 & 73 & 116 & 3.121 \\
\hline 0.0 .5 .33 .2 .3 .12 & 6301 & Postreplication repair & 3 & 4 & 4 & 2.905 \\
\hline 0.0 .5 .35 .3 .4 & 723 & telomere maintenance & 0 & 0 & 0 & 2.289 \\
\hline 0.0 .5 .35 .3 .4 .0 & 7004 & $\begin{array}{l}\text { Telomerase-dependent } \\
\text { telomere maintenance }\end{array}$ & 4 & 8 & 15 & 2.289 \\
\hline
\end{tabular}

